Retraction

\title{
Retracted: Multidimensional Fragility Analysis for a NEES Frame Structure by Integrating a New Energy Damage Index: Cumulative Plastic Strain
}

\author{
Advances in Civil Engineering
}

Received 8 June 2020; Accepted 8 June 2020; Published 30 July 2020

Copyright (c) 2020 Advances in Civil Engineering. This is an open access article distributed under the Creative Commons Attribution License, which permits unrestricted use, distribution, and reproduction in any medium, provided the original work is properly cited.

\begin{abstract}
Advances in Civil Engineering and the authors have retracted the article titled "Multidimensional Fragility Analysis for a NEES Frame Structure by Integrating a New Energy Damage Index: Cumulative Plastic Strain" [1], due to an error identified by the authors in the seismic wave selection that leads to serious errors in the final calculation results. The Energy Damage Index: Cumulative Plastic Strain constructed in the article is therefore incorrect and the article is being retracted at the request of the authors.
\end{abstract}

\section{References}

[1] Q. Wang and Z. Wu, "Multidimensional Fragility Analysis for a NEES Frame Structure by Integrating a New Energy Damage Index: Cumulative Plastic Strain," Advances in Civil Engineering, vol. 2019, Article ID 7323656, 11 pages, 2019. 